\title{
Overcoming Shyness: Promoting Leadership and Communication through English Drama Camp in Japan
}

\author{
Yasuko Shiozawa \& Eucharia Donnery
}

\begin{abstract}
The purpose of this paper is to describe how drama-based pedagogies can meet Japanese university EFL students learner-needs within a short timeframe. It first describes the cultural and educational contexts of Second Language Acquisition (SLA) in Japan in general terms, before specifically outlining the aims and methodology of the 2014 and 2015 summer drama camps. The paper then moves into the crux, that of the aims, student profiles, methodology and results of the 2016 summer drama camp, which focused on the theme of homelessness. The paper concludes by arguing the validity for the more widespread adoption of drama-based pedagogies in the Japanese university EFL context.
\end{abstract}

\section{Introduction}

This paper discusses the significance of three-day summer drama-workshops conducted between 2014 and 2016, and focuses on the 2016 camp in particular. Participants of this latter workshop were English as a foreign language (EFL) students of Bunkyo University under the guidance of Yasuko Shiozawa and students of Nihon University under the direction of Takashi Kanazashi. The workshop was designed and facilitated by Shiozawa and Eucharia Donnery, and co-facilitated by Kanazashi and Yuka Kusanagi.

The main aims of each of the short-programs were to develop leadership skills and comunicative abilities. In addition, the workshop in 2016 endeavoured to develop interest in and an understanding of the socially disadvantaged as the overall theme. Students were actively encouraged to speak in English to the best of their abilities, although actual analytical discourses and creative preparations took place in Japanese. As the latter was entirely learner-centered, this became an integral part of the team-building process.

Because the overall theme of the workshop was homelessness, the case-studies that the students read were framed through various contemporaneous contexts: the difficult journeys of refugees en route to Europe, adaption issues of refugees 
living in the UK, the plight of Fukushima nuclear evacuees four years on, the life of a homeless young woman in the US, an elderly man collecting empty cans to earn some money to feed himself in Japan, and "industrial trainees" brought semi-legally to Japan (see appendix II for details). Through working performatively, the students' self-efficacy could "successfully execute the behavior to produce the outcomes" (Bandura, 1997:193) in order to personalize abstract and difficult themes to engage meaningfully with others, as well as to promote teambuilding and friendship. This paper reports on the outcomes and challenges stemming from the inclusion of drama-based pedagogy into EFL education in the Japanese university context.

\section{Cultural Specificity of Japan}

There are three important considerations when describing the average Japanese university student: fear of strangers/ shyness, tacit understanding and modesty/ self-restraint.

\subsection{Fear of Strangers/ Shyness}

A Japanese cultural trait that renowned psychiatrist Doi highlights is "the word hitomishiri, literally coming to know people... is usually translated in dictionaries simply as 'shyness' or 'bashfulness"' (Doi 1971: 105). Hitomishiri is the shyness that can manifest into a fear of others, which combined with a culture of dependence, what Doi calls amae, means that shyness is not seen in a negative light within Japanese culture. With respect to shyness, Craighead \& Nemeroff report that $57 \%$ of Japanese university students describe themselves as "shy", as opposed to a mere $31 \%$ of their Israeli counterparts (Craighead \& Nemeroff 2001: 1523). They attribute this to differences between collectivistic and individualistic cultures; however, in addition to Doi's theory of amae, there are other complex cultural reasons why Japanese society formulates shyness as a part of self-image (ibid. 16). In Japan, if a child is successful, then praise is given to the parents, the teachers, Japanese society as a whole and, traditionally, Buddha. However, should that same child fail, he or she fails alone. Even Japanese adults are not immune to debilitating bouts of shyness, especially when dealing with new situations. As far back as 1860, prominent educator and entrepreneur Yukichi Fukuzawa described his arrival in San Francisco as follows:

Before leaving Japan, I, the independent soul - a care-free student who could look the world in the face - had feared nothing. But on arrival in America, I was turned suddenly into a shy, self-conscious, blushing 'bride'. The contrast was funny, even to myself. (Fukuzawa 1981: 114)

This clearly shows a link between meeting people and shyness within the Japanese psyche that can manifest itself as a fear of strangers and of "Otherness" in general. This fear-of-the-unknown anxiety is palpable in the first 
day of class or work situation and can have a debilitating effect on relationships and group dynamics. There is good reason for this fear, as Hofstede (1991: 113) ranks Japan at number seven when it comes to Uncertainty Avoidance; furthermore he argues that the corresponding adherance to regulation is a result of the propensity for natural disasters. The benefit of this is that the infrastructure is reliable and smooth-running; however there are also correspondingly high levels of anxiety and stress.To counteract this shyness and fear of the unknown, universities and companies spend an inordinate amount of time on orientations and team-building in order to create a sense of group and foster group loyalty, through what Rohlen \& LeTendre describe as "helping us appreciate the oft-mentioned shuudan seikatsu (group living)" (Rohlen \& LeTendre 1998: 62). Therefore, given the circumstances, it is understandable that the average modern Japanese student is reluctant to draw attention to himself or herself and shuns the limelight for fear of failure, which is a solo burden to bear.

For the purpose of this paper, drama-based pedagogy was used to help foster a sense of a cohesive group in which each individual student has an important part to play. With respect to the Japanese university class, drama-based pedagogies can particularly benefit shy and socially withdrawn students through a more holistic approach to learning and by the value of working in small, intimate groups. Starting with non-verbal improvisational activities in which even the quietest student can partake, the process of team-building is developed through the addition of two-dimensional expression games and finally into small group activities (see appendix I). This framework allows each student to contribute to the extent of his/her psychologically comfortable limits, both for the shyer students and those with language anxiety.

\subsection{Tacit Understanding}

Heightened sensitivity, or tacit understanding, is an essential part of the Japanese culture, and one in which most Japanese take pride. In Japanese, a language where words devalue the preciousness of emotion, the pinnacle of successful communicative competence is non-linguistic. According to cross-cultural theorists such as Hofstede and Hall, while the more explicit English communicative style tends to rely on the active pursuit of information, the implicit Japanese communicative style relies on empirical and shared knowledge, which is highly contextualized. Information surrounds the person and adherence to group norms and/or consensus is of utmost importance. An example of this implicit communication at work can be seen every day in Shinjuku Station, Tokyo. Three and a half million people pass through this station each day, making it one of the busiest train stations worldwide, yet there is little confusion because all the information referring to train lines, including cost, is clearly signposted on the walls of the station. This exemplifies the implicit nature of the Japanese language; information is all around and it is unnecessary, in many cases, to actively seek out information and/or clarification. In 
contrast, European languages are generally considered explicit, or low-context, as acquisition of all available information is necessary for comprehension. This also means that, unlike Japanese and other implicit languages, silence is not recognized as a useful tool for communication in many contexts. English, for instance, emphasizes a more ontological understanding and the accumulation of hard information for assimilation, demonstrating its low context nature. As a result, English speakers tend to actively seek out information and can be relentless in questioning in the pursuit of complete understanding. Within the Japanese cultural context, this can sometimes be misconstrued as rude and intrusive as, culturally, the Japanese information-seeker tends to be more circumspect and indirect. As Hall describes:

that ... insistence on 'coming to the point' quickly is just as frustrating to the Japanese, who do not understand why we have to be so 'logical' all the time (Hall 1990: 151)

In addition to this, from the Japanese learner's perspective, English has an astonishing amount of gaps in information that the Japanese learner is reluctant to question.

This implicit nature of the Japanese language means that it is important to be able to read between the lines, rather than take meaning at face value and there is considerable attention paid to non-verbal cues and/or other clues. Because of the explicit nature of English, the responsibility for the success or failure of communication lies with the speaker, whereas, in Japanese, the onus for this success or failure in communication is on the listener. This difference in communicative styles where there is little value placed on the ability to read between the lines and ambiguity is not condoned, means that many interactions in English can be fraught with difficulties for the average Japanese person. It also means that in the Japanese EFL class, the silence can be deafening as students are conforming to cultural norms by trying to understand, rather than actively seeking out more information from the teacher or each other. Additionally, students are extremely reliant on written materials such as hand-outs and textbooks. Therefore, the use of drama-based pedagogies can address learner needs by offering a psychologically safe environment in which students can both generate and explore most information in a learner-centered and learning-centered way through collaboration with strangers, pro-active information-seeking, and problem solving.

\subsection{Modesty and Self-restraint}

Within Japanese cultural norms, compliments are received with a mixture of embarrassment and self-effacement. The reason behind such behaviour is modesty and fear of being perceived as boastful in any way. However, in Japanese culture, there is also the additional issue of enryo, or self-restraint. As Doi points out, "The Japanese, generally speaking, tend to dislike enryo in themselves but expect it in others" (Doi 1971: 39). Therefore, in Japanese 
culture, there is an expectation that people will be controlled in social situations. This is what De Mente describes as "a way of coping" that "stifled the individuality and creativity of the Japanese and held them in harsh bondage to the state" (De Mente 2004: 14). However, in the realm of domesticity and with close friends, this coping strategy is not necessary and can disappear completely, allowing for frank and open discussion to occur. Therefore, if drama-based pedagogies in the Japanese university EFL classroom could facilitate this freedom from enryo, then students would be more relaxed yet simultaneously engaged.

Another offshoot of this self-restraint is humility. Japanese people tend to downplay any talents in the oft-heard phrase "not being very good at something". This has serious implications for the Japanese EFL class, as students can get into self-fulfilling prophecies that their English is "not very good" and become demotivated. Therefore, it is vital that this aspect of Japanese culture be understood by educators so that they can support their students on their linguistic journeys. Students themselves also need to understand this false modesty so they can validate this part of Japanese culture while simultaneously moving beyond it to acculturate in English.

\section{English Education in Japan}

Compulsory education in Japan consists of nine years: six years of elementary school starting at the age of six, followed by three years of junior high school. More than $90 \%$ of students go on to senior high school for a further three years, while about half go into higher education (World Bank Data). English-language education starts in junior high, so the average Japanese university student has been taught English as a core-subject for six years or more. Since 2014, the Japanese Ministry of Education, Culture, Sports, Science and Technology (MEXT) government has introduced English compulsory education from elementary school level. However, like the major issue at the junior and senior high school levels, there is the major problem of inadequate teacher-training in English language education.

Despite all the government support for English language education, the average Japanese person has no difficulty living in Japan without a command of English, as most necessary knowledge and information can be obtained in Japanese. Therefore, it seems that the primary purpose of Japanese secondary school students learning English is solely to obtain high scores in exams, especially in the entrance exams for the higher levels of education, which focus mainly on reading and grammar as can be seen in Figure 1 below:

The major activities in English classes are reading aloud and pronunciation, along with grammar explanations and simple comprehension questions (see figure 2 below).

Indeed, the teachers themselves are cognisant of their own linguistic and teaching shortcomings; more than $60 \%$ of secondary school teachers are not confident in their own communication skills and are unsure about effective teaching methods (see figure 3 below). 


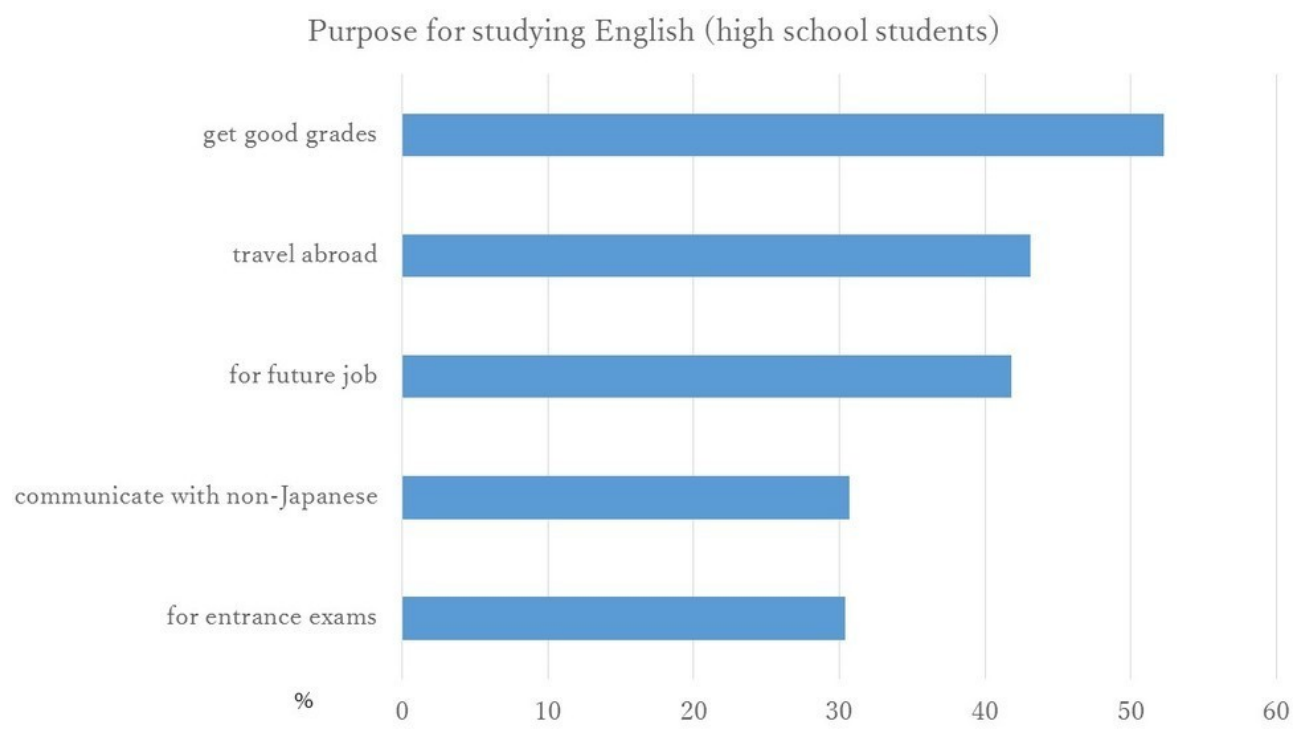

Figure 1: Purpose for Studying English (High School Students), 2016 Ministry of Education and Science Data (Author Interpretation)

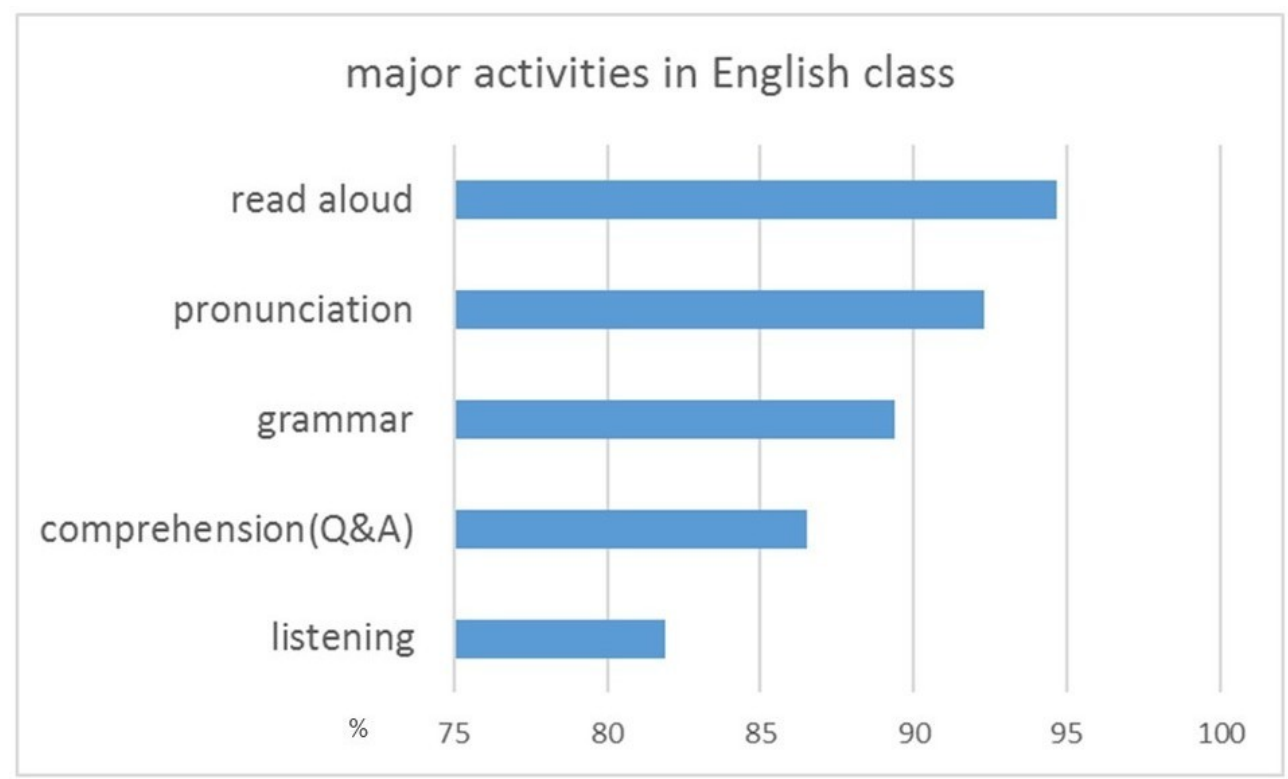

Figure 2: Major Activities in English Class, 2016 Benesse (Author Interpretation) 
English teachers' concerns about themselves

\section{lack of own English proficiency}

\section{know no effective teaching methods}

$\%$

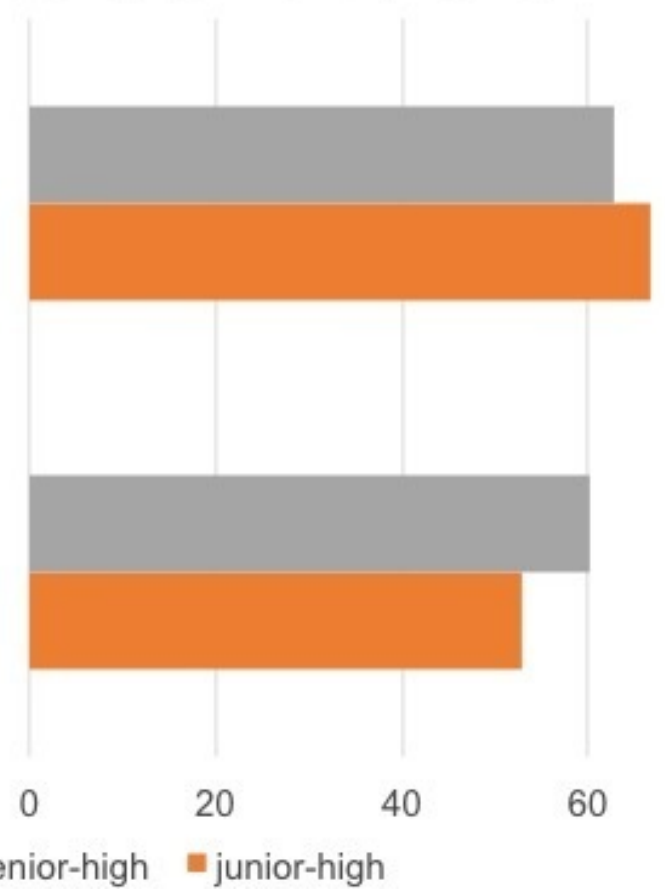

Figure 3: English Teachers' Self-efficacy, 2016 Benesse (Author Interpretation)

Accordingly, the classes may develop receptive English language abilities, but not productive skills such as speaking and writing.

Once the students enter university, many harbour a desire to be able to function in English in the future; students realize the necessity of English as a global business language. However, the opportunities to actively communicate in English are limited to the classroom and a few scattered occasions in everyday life. Some students study English independently in order to boost their TOEIC scores, a standard business English proficiency test used widely as a benchmark of English language abilities in the Japanese corporate world. Still others continue studying merely to accumulate credit towards the ultimate goal of graduation, once again resulting in low communicative English language skills. In conclusion, the compulsory English education is study-based, exam-focused and taught as a mathematical formula, and this is why drama-based pedagogies can address learner needs by giving students techniques to develop English communication skills, as well as interpersonal and social skills.

\section{Past Summer Drama Camps}

From 2014, a number of universities, including that of one of the authors, started to hold intervarsity intensive three-day summer drama camps in seminar 
houses, which aimed to develop English communication skills and leadership skills. The basic design was modelled on the Philippines Educational Theater Association (PETA) workshops for educators and facilitators. More than 50 students and five EFL teachers from four different colleges participated in the 2014 workshop. After a series of warm-up activities involving improvisation and theatre games, the students were divided into small groups of five or six people. The main activity was for each group to create a three-to-five minute drama about their dreams of college life and showcase it in the final performance. The teachers took turns facilitating a variety of activities, such as readers' theatre, short story telling, and dancing, while the participating students were also in charge of some warm-up games.

In 2015, a professional British actor was employed as the main facilitator. Based on close communication with the teachers, he led a series of exciting improvisation activities focusing on characterization. This time, the participants were 34 students from two colleges. The main activity was similar to that of the previous year: group creative drama inspired by recent news with a showcase performance, which most dramatized in the form of a news show including live reports.

The results of the 2015 summer drama camp were crucial in developing the structure and in the implemention of the framework for the drama camp of 2016. There were pre- and post-surveys administered before and after the 2015 summer drama workshop, which focused on the participants' perceptions of their social and academic skills. As can be seen in Figure 2 below, the results showed that the drama workshop significantly increased the participants' self-awareness of their abilities to survive and thrive: in particular within the nine areas of motivation, adaptability, stress tolerance, assertiveness, persuasiveness, leadership skills, logical thinking, problem solving and negotiation skills. Intriguingly, the results indicated that English ability was the one item that scored lower after the workshop. Some participants felt frustration with their English abilities, which may itself have resulted in the lower score. This was not statistically significant; however, further investigation would be required to ascertain the reason for this anomaly. Although these results merely revealed the students' self-efficacy, they promisingly suggested that drama-based pedagogy can holistically address Japanese university EFL students' needs (see figure 4 below).

2015 PRE AND POST WORKSHOP SELF-RATING OF BASIC SOCIAL SKILLS

\section{Summer Drama Camp 2016}

With worldwide concern over the escalating refugee crisis, the aim of the 2016 summer drama camp was to encourage Japanese students to consider and empathize with the plight of the homeless by living through the difficulties of those socially disadvantaged through drama-based pedagogy. 


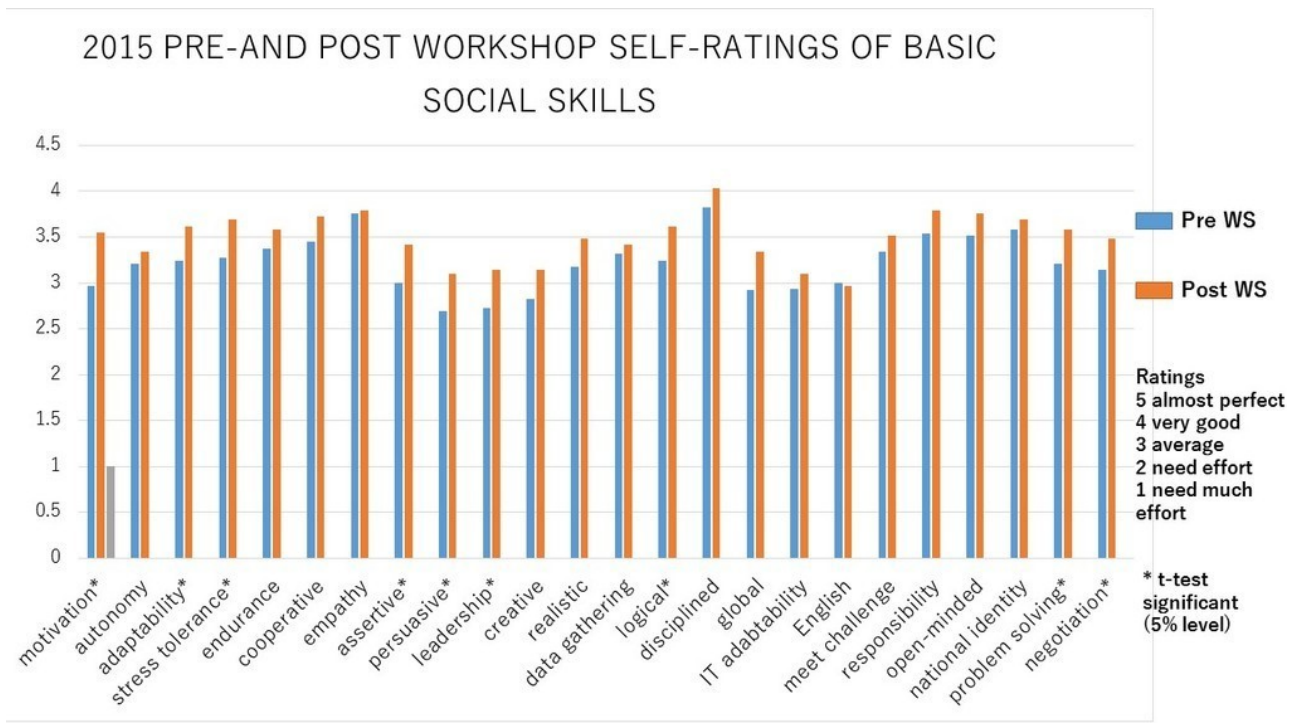

Figure 4: 2015 Student Self-efficacy

\subsection{Aims of the Summer Drama Camp}

The overt aim of the 2016 summer drama camp was the development of leadership skills in tandem with communicative abilities. With respect to the latter, there were goals to make positive changes in Kao and O'Neill's five areas of open communication: fluency, authenticity, confidence, challenge (which was interpreted within the context of Japanese English education as the change from instrumental motivation to a more integrative one) and new classroom relations (see figure 5 below and appendix II).

Table 1: 16)

\begin{tabular}{|c|c|c|c|}
\hline $\begin{array}{l}\text { Drama } \\
\text { Approaches } \\
\text { Key Aspects }\end{array}$ & $\begin{array}{l}\text { Closed } \\
\text { Communication }\end{array}$ & Semi-Controlled & $\begin{array}{l}\text { Open } \\
\text { Communication }\end{array}$ \\
\hline Objectives & $\begin{array}{l}\text { 1. accuracy } \\
\text { 2. practice } \\
\text { 3. confidence }\end{array}$ & $\begin{array}{l}\text { 1. fluency } \\
\text { 2. practice } \\
\text { 3. authority } \\
\text { 4. challenge }\end{array}$ & $\begin{array}{l}\text { 1. fluency } \\
\text { 2. authenticity } \\
\text { 3. confidence } \\
\text { 4. challenge } \\
\text { 5. new } \\
\text { classroom } \\
\text { relations }\end{array}$ \\
\hline
\end{tabular}


To this end, the project was designed so that it would engage and resonate with students by giving them meaningful roles with purposeful tasks and clear goals. To maximize dramatic tension, there was a sense of urgency with a dilemma, secrecy and withheld information and the need for students to find the optimal conflict resolution.

\subsection{Student Profile}

Out of 42 participants, 20 were $3^{\text {rd }}$ and $4^{\text {th }}$ year students (aged between 20 and 22) majoring in International Studies at Bunkyo University, and were part of a seminar class specializing in oral communication activities. In addition, about half of them had experienced creating and performing drama in English twice in public and, thanks to their major, most were interested in English communication. The other 22 were $2^{\text {nd }}$ to $4^{\text {th }}$ year students from Nihon University (aged between 19 and 22), and were majoring in commerce. Their teacher, Mr. Takeshi Kanazashi, was an exceptional role model in that he almost always spoke English with them and encouraged them to also use English whenever possible. The two groups of students met at the camp for the first time. For both groups of students, participation in this camp was part of their seminar class and their linguistic abilities in English were similar, varying a great deal from false beginner to high-intermediate.

\subsection{Methodology}

The warm-up activities involved both verbal and non-verbal improvisational activities, some of which were devised and directed by the students (see appendix I). In the middle of the workshop, the participants were divided into groups of four to six students, engaged in team-building strategies. As a warm-up to the discussion on involuntary homelessness, half the students (Group A) within the groups were asked to leave the class. When they returned, the other students (Group B) had taken their belongings and claimed that they now belonged to them. Students in Group A knew that this could not possibly be the case, however reactions ranged from nervous laughter to shock. To debrief, there was an amateur video clip called "Stereotypes and Prejudices" shown to demonstrate the dangers of isolating people because of ethnicity, religion, and/or race. From there, the students had a five-minute discussion in Japanese on the subject of personal violations such as robbery or identity violations such as being hacked. There was a video tracing the journey of a Syrian refugee to Europe from the perspective of his iPhone, which was the basis for the second five-minute discussion about how modern technology can help refugees and other victims of homelessness in the $21^{\text {st }}$ century.

After the students familiarized themselves with each other in the group, they were given articles related to the theme of homelessness: the diaries of some international refugees worldwide; foreign trainee problems in Japan; news articles on homeless people in Japan and the difficult lives of Fukushima 
residents affected by nuclear accidents, to name a few (see appendix II). The students were asked to interpret and produce a story by acting out the most memorable scenes from the articles. The structure was as follows:

- read the article and seek understanding through collaborative endeavour

- decide on the message of their drama to convey to the audience

- devise a plot and write the outline

- decide on the roles

- perform the drama

\section{Results}

\subsection{Student Produced Mini-drama Showcase}

By the time the news articles had been distributed, the students' fear of strangers as described in Section 2.1 had diminished to such an extent that they were comfortable enough in each others' company enough to interact with each other in the improvisation games of Section 5.3. The development of their group identity was also facilitated by a series of extra activities designed to enhance group dynamics. Each group of students spent substantial time and energy creating drama-performances based on their target article (see appendix II). To encourage all the students irrespective of linguistic ability or personality, the facilitators suggested that they utilize the essence of the article rather than try to recreate it verbatim so that they put their own creative stamp on the work. During the final performance showcase, all the groups performed sufficiently well to get their message across, although many still exhibited hesitation and shyness.

\subsection{Student Voices}

In order to qualitatively review and analyze the students' comments in the aftermath of the 2016 summer drama camp, the data was organized by the Kawakita Jiro (KJ) Method in which large numbers of overlapping ideas are placed into groups. Therefore, the voices of many students have been condensed into a single student's comment to demonstrate how Kao and O'Neill's five areas of open communication relating to the aims of the workshop, as outlined in Section 5.1, were successful (see figure 6 below).

These observations clearly demonstrate a growing self-efficacy within both communicative and social skills, as well as learning that occurs on a deeper and more integrative level. There was one lone voice of dissent which exemplifies the internal struggle to overcome cultural tendencies to fear of strangers and shyness, as detailed in Section 2.1, "the difficulty in meeting people for the first time and communicating with them was real." 


\begin{tabular}{|l|l|}
\hline Area & Student Comment \\
\hline Fluency & "It became easier to express my ideas in English. It was a lot of fun" \\
\hline Authenticity & $\begin{array}{l}\text { "To go from meeting strangers and discussing, then performing, about } \\
\text { very deep issues, was an achievement and an ultimately enriching } \\
\text { experience" }\end{array}$ \\
\hline $\begin{array}{l}\text { Confidence } \\
\text { (Motivation) }\end{array}$ & $\begin{array}{l}\text { "Even though I don't understand English grammar, I was able to express } \\
\text { myself without overthinking. I think that this was important." }\end{array}$ \\
\hline $\begin{array}{l}\text { New } \\
\text { Classroom } \\
\text { Relations }\end{array}$ & $\begin{array}{l}\text { "Even though we were meeting people for the very first time, from the } \\
\text { outset the conversations flowed smoothly and we came to believe in our }\end{array}$ \\
\hline
\end{tabular}

Figure 5: 16)

\section{Conclusions}

English language has a special status in Japan, the majority of Japanese regard English as a lingua franca and would like to be able to function in English in a variety of situations in everyday life. However, from a self-efficacy perspective, most do not have sufficient communicative abilities despite "studying" English instrumentally for more than six years in order to pass examinations. This is perhaps due to lack of opportunities to use English outside the class, and accordingly there is little motivation for more integrative learning to occur. As mentioned in Section 3, there are also problems within teacher-training with respect to the best practices to help, support and encourage students on their linguistic and social journeys.

Drama-in-Education (DiE) is an area that is practiced at school and university annual festivals in Japan; however, drama-based pedagogies are rarely used in class. By taking drama into the university EFL class, even within the context of a stand-alone intensive annual three-day drama workshop, the power that drama can confer on the students both linguistically and socially can be seen in the positive evaluations of the participants themselves.

As the results indicate, the very nature of the drama workshops, which focus on communicative meaning rather than grammatical accuracy, is highly learner and learning centered. Through the warm-up activities such as improvisation, students were able to relax in each others' company. The facilitators could observe how the participants, typically shy and modest, were able to extensively discuss and create their drama, while rehearsing it over and over again utilizing 
their bodies and the physical space. While some of the tasks may initially have been quite daunting, such as reading and comprehending rather long texts on social issues in English, through collaborative engagement, all groups were able to produce and perform meaningful work.

Acknowledgements:

Thanks to the grant-in-aid for scientific research (\#26381223) awarded by the Japan Society for the Promotion of Science, the personal cost for each student was kept to a minimum.

The 2017 summer drama camp with Bunkyo University and Shonan Institute of Technology was held in September and this new data is being currently compiled for upcoming research.

\section{Bibliography}

Bandura, Albert (1977): Self-efficacy: Toward a Unifying Theory of Behavioral Change. Psychological Review. 84. 2, 191-215.

Craighead, W. Edward \& Nemeroff, Charles B. (eds.) (2001): The Corsini Encyclopedia of Psychology and Behavioral Science (3rd ed.) 4, 1522-1523. New York: Wiley

De Mente, Boye Lafayette (2004): Japan's Cultural Code Words: 233 Key Terms that Explain the Attitudes and Behavior of the Japanese. MA: Tuttle

Doi, Takeo (1971): The Anatomy of Dependence: The Key Analysis to Japanese Behavior. Trs. John Bester. New York: Kodansha

Fukuzawa, Yukichi (1981): The Autobiography of Yukichi Fukuzawa (trans. Eiichi Kiyooka). Tokyo: Hokuseido

Hall, Edward Twitchell (1990): The Hidden Dimension: Doing Business with the Japanese. New York: Anchor

Hofstede, Geert (1991): Cultures and Organizations: Software of the Mind. Intercultural Cooperation and its Importance for Survival. New York: Macmillan

Kao, Shin Mei \& O’Neill, Cecily (1998): Words into Worlds: Learning a Second Language Through Process Drama. Connecticut: Greenwood

Rohlen, Thomas \& LeTendre, Gerald (eds.) (1998): Teaching and Learning in Japan. Cambridge: Cambridge UP

World Bank Data. http://databank.worldbank.org/data/Views/Reports/ReportWidgetCustom.aspx?Report_Name=C [last accessed November 13, 2017] 


\section{A Appendix I: 2016 Drama Workshop Camp Improvisational Activities}

1. Non-verbal Improvisational Activities (Warm-ups)

2. Send hand-claps

3. Count up / down

4. 7 up

5. Zip-zap-bang

6. 10-second tableau

7. Two-dimensional Expressions

In this, participants line up according to the order of the target element: distance, length, and enjoyment of part-time work. They then rotate up and down through these target elements.

- Distance between their place and the hotel + how excited they are about this workshop

- Length of their hair / arms

- Part-time Jobs: hours and enjoyment

\section{Group Activities}

1. Memory Chain: Self-introductionMake group chants based on common traits among members $>$ make poster presentation

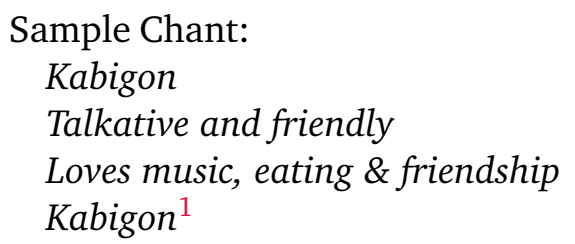

\footnotetext{
${ }^{1}$ Kabigon is the name of a monster in Japanese animation
} 


\section{B Appendix II: Article Titles}

1. Brasor, Philip (June 13, 2015): Japan's Masochistic Approach to Immigration. In: TheJapan Times. https://www.japantimes.co.jp/news/2015/06/13/national/medianational/japans-masochistic-approach-immigration/\#.WgkOWoZx10s [last accessed November 13, 2017]

2. Hamaguchi, Keiiichiro (July, 24, 2013): Addressing the Problems with Japan's Peculiar Employment System. In: Nippon.com. http: //www.nippon.com/en/currents/d00088 [last accessed November 13, 2017]

3. Ito, Masami (April 9, 2013): Foreign Trainee System said still Plagued by Rights Abuses. In: The Japan Times https://www.japantimes.co.jp/ news/2013/04/09/reference/foreign-trainee-system-said-still-plaguedby-rights-abuses / [last accessed November 13, 2017]

4. Murai, Shinsuke (January 6, 2016): Government weighs Immigration to Maintain Population, Boost Workforce. In: The Japan Times . https://www.japantimes.co.jp/news/2016/01/06/national/ social-issues/government-weighs-immigration-maintain-populationboost-workforce/ [last accessed November 13, 2017]

5. Ripley, Will; Ogura, Junko \& Griffiths, James (March 11, 2016): Fukushima: Fiveyears after Japan's worst nuclear disaster from Fukushima disaster 5 years on: How it changed Japan http://edition.cnn.com/ 2016/03/08/asia/fukushima-five-year-anniversary/index.htmlCNN.com March 8, 2016 [last accessed November 13, 2017] 
C Appendix III: Kao and O'Neill's 'Summary of the differences in key aspects of three drama approaches" (1998: 16) 


\begin{tabular}{|c|c|c|c|}
\hline $\begin{array}{l}\text { Drama } \\
\text { Approaches } \\
\text { Key Aspects }\end{array}$ & $\begin{array}{l}\text { Closed } \\
\text { Communication }\end{array}$ & Semi-Controlled & $\begin{array}{l}\text { Open } \\
\text { Communication }\end{array}$ \\
\hline Objectives & $\begin{array}{ll}\text { 1. } & \text { accuracy } \\
\text { 2. } & \text { practice } \\
\text { 3. } & \text { confidence }\end{array}$ & $\begin{array}{ll}\text { 1. } & \text { fluency } \\
\text { 2. } & \text { practice } \\
\text { 3. } & \text { authority } \\
\text { 4. } & \text { challenge }\end{array}$ & 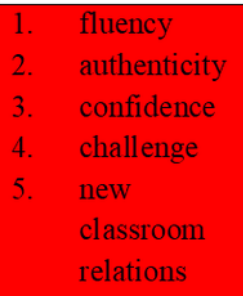 \\
\hline Organization & $\begin{array}{ll}\text { 1. } & \text { pair work } \\
\text { 2. } & \text { small } \\
& \text { groups } \\
\text { 3. } & \text { rehearsal }\end{array}$ & $\begin{array}{ll}\text { 1. } & \text { small groups } \\
\text { 2. } & \text { some rehearsal } \\
\text { 3. } & \text { unpredictable } \\
& \text { ending }\end{array}$ & $\begin{array}{ll}\text { 1. } & \text { usually } \\
\text { begins with } \\
\text { large group } \\
\text { 2. pair work } \\
\text { and small } \\
\text { groups as } \\
\text { work } \\
\text { continues }\end{array}$ \\
\hline Context & $\begin{array}{ll}\text { 1. } & \text { simple } \\
\text { 2. } & \text { naturalistic } \\
\text { 3. } & \text { teacher } \\
& \text { selected }\end{array}$ & $\begin{array}{l}\text { 1. determined by } \\
\text { students in } \\
\text { consultation } \\
\text { with teacher }\end{array}$ & $\begin{array}{l}\text { 1. launched by } \\
\text { teacher in } \\
\text { role } \\
\text { developed } \\
\text { with } \\
\text { students' } \\
\text { input }\end{array}$ \\
\hline Roles & 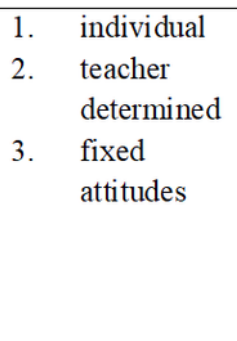 & $\begin{array}{ll}\text { 1. } & \text { group } \\
\text { members } \\
\text { 2. } & \begin{array}{l}\text { spokespersons } \\
\text { groups }\end{array} \\
\text { 3. } & \text { individual } \\
\text { role-taking }\end{array}$ & $\begin{array}{l}\text { 1. } \text { generalized } \\
\text { at first } \\
\text { 2. becoming } \\
\text { individualiz } \\
\text { ed at at } \\
\text { students' } \\
\text { own choice } \\
\text { later }\end{array}$ \\
\hline Decisions & 1. none & $\begin{array}{l}\text { 1. } \begin{array}{l}\text { determined by } \\
\text { students }\end{array}\end{array}$ & $\begin{array}{l}\text { 1. negotiated } \\
\text { by students }\end{array}$ \\
\hline Tension & $\begin{array}{l}\text { 1. to produce } \\
\text { accuracy of } \\
\text { language } \\
\text { and } \\
\text { vocabulary }\end{array}$ & $\begin{array}{l}\text { 1. arising from } \\
\text { the social } \\
\text { dynamic rather } \\
\text { than a focus on } \\
\text { accuracy }\end{array}$ & $\begin{array}{l}\text { arising from } \\
\text { the dramatic } \\
\text { situation and } \\
\text { the } \\
\text { intentions of } \\
\text { the roles }\end{array}$ \\
\hline Teacher & 1. to set up & 1. to initiate & in role \\
\hline
\end{tabular}

